В. В. Артьоменко, В. М. Носенко

Одеський національний медичний університет

\title{
ПЕРШИЙ ДОСВІД СИМУЛЯЦІЙНОГО НАВЧАННЯ СТУДЕНТІВ ШОСТИХ КУРСІВ МЕДИЧНИХ ФАКУЛЬТЕТІВ
}

\author{
V. V. Artomenko, V. M. Nosenko \\ Odessa National Medical University
THE FIRST EXPERIENCE OF SIMULATION EDUCATION OF ${ }^{\text {TH }}{ }^{\text {YEAR }}$ MEDICAL FACULTY STUDENTS

\begin{abstract}
Мета роботи - аналіз перших результатів досвіду організації підготовки студентів шостих курсів медичних факультетів на основі інноваційних симуляційних технологій.

Основна частина. Важливим для медичної освіти в Україні стало створення на базі Одеського національного медичного університету Навчально-інноваційного центру практичної підготовки лікаря і кафедри симуляційної медицини. Вони $є$ базами сучасної підготовки студентів і лікарів. Вивчено результати навчання і оцінювання 450 студентів шостих курсів медичних факультетів. За результатами підсумкового тестування та заліку було виявлено, що низькі початкові оцінки за темами діагностики та лікування невідкладних станів достовірно збільшилися в два рази. Оцінка командної роботи в кінці циклу зросла майже в два рази.

Висновок. Використання симуляційних технологій дозволяє підвищити ефективність навчання студентів шостих курсів медичних факультетів.
\end{abstract}

Ключові слова: медична освіта; симуляційна медицина; практичні навички; робота в команді; студенти медичних факультетів.

The aim of the study - analysis of first results of experience of 6th year medical faculty students training on the basis of innovative simulation technologies.

The main body. Establishing Educational innovative center for the doctors' practical training and Department of simulation medicine on the basis of Odessa State Medical University was important for medical education in Ukraine. They are the bases of the students and doctors training nowadays. The learning outcomes and assessment of 450 sixth year students of medical faculties are studies. According to the results of the final tests it was found that low initial grades of the practical skills on the diagnosis and treatment topics significantly increased twofold. Teamwork evaluation at the end of the course has increased about twofold.

Conclusion. The simulation technologies use significantly increases the teaching effectiveness of practical skills improvement for sixth year students of medical faculties.

Key words: medical education; simulation medicine; practical skills; teamwork; students of medical faculties.

Вступ. У зв’ язку з новою навчальною програмою студенти шостих курсів медичних факультетів 3 2016 року мають можливість пройти навчання на кафедрі симуляційної медицини та в Навчальноінноваційному центрі практичної підготовки лікаря ОНМедУ (далі - Центр). Вони мають цикл 3 симуляційної медицини.

Мета роботи - аналіз перших результатів досвіду організації підготовки студентів шостих курсів медичних факультетів на основі інноваційних симуляційних технологій.

Основна частина. У 2014 році на базі Одеського національного медичного університету були створені перший на території України Навчально-іннова-

(C) В. В. Артьоменко, В. М. Носенко ційний Центр практичної підготовки лікаря (даліЦентр) та кафедра симуляційної медицини (провідна кафедра в Україні з симуляційної медицини). Головне - розробка нових інноваційних підходів до медичної освіти України, в тому числі й удосконалення сучасної освіти студентів медичних вищих навчальних закладів. Одними з основних напрямів діяльності Центру та кафедри стали: 1) виявлення нових підходів до медичної освіти; 2) розробка цілісної системи симуляційного навчання; 3) забезпечення цієї системи навчально-методичними та науковими складовими; 4) відпрацювання студентами, інтернами та лікарями-курсантами теоретичних і практичних навичок діагностики та лікування патологічних станів, розвиток у них здатності швидко 
приймати правильне рішення; 5) набуття досвіду ефективної командної роботи при міждисциплінарних тренінгах $[1,2]$. У результаті творчої науководослідної роботи були отримані власні методики як з боку педагогічних, так і практичних аспектів підготовки медичних працівників. Центр є структурним підрозділом університету. У своїй діяльності Центр керується чинним законодавством України. Для ефективної роботи Центру передбачена взаємодія і співпраця з університетськими кафедрами, клініками, лікарнями та медичними центрами, місцевими та регіональними управліннями охорони здоров'я, громадськістю, провідними асоціаціями медичних працівників, провідними світовими навчальними симуляційними центрами та іншими організаціями. Весь науково-педагогічний колектив Центру пройшов навчання в провідних симуляційних центрах Європи та США. Окрім цього, до роботи у Центрі залучається науково-педагогічний колектив кафедри симуляційної медицини, інших кафедр та структурних підрозділів університету. Залучені працівники кафедр беруть участь у консультуванні, розробці, плануванні та проведенні наукової, науково-методичної роботи Центру, тим самим забезпечуючи міждисциплінарну інтеграцію та взаємодію між структурними підрозділами університету. Центр це спеціальна структура, яка оснащена необхідним обладнанням для занурення особи, що навчається, в середовище, максимально наближене до реального.

Головні види тренінгів під час симуляційного навчання в Центрі проводяться на найсучаснішому обладнанні, в тому числі на роботах та манекенах high-fidelity класу. Використовується навчання на анатомічному симуляторі (4D скани). Базова медична практика проводиться на моделях та симуляторах із низьким та середнім рівнями складності, для яких можна використовувати УЗ-навігацію, моніторинг. Використовуються також ультразвукові діагностичні системи. Велике значення мають віртуальні операційні, комп’ютерні симулятори. Окремо треба відзначити мультидисциплінарні та командні тренінги.

Протягом дебрифінгу, який завершує та доповнює виконання сценарію, інструктор разом із психологом проводить детальний аналіз результатів навчання та розробляє єдиний алгоритм дій у певній ситуації.

Також для оптимізації роботи Центру немаловажну роль відіграє технічно-комунікаційне обслуговування Центру - це й IT-підтримка, системи звуко- та відеозапису і відтворення, системи гене- рації звітів з інтегрованим календарем та графіком, спеціалізоване медичне обладнання та витратний матеріал, завдяки якому особа, що навчається, має можливість максимально реалістично зануритись в умови тієї чи іншої клінічної ситуації.

Симуляційне навчання в 2016 році пройшли більш ніж 450 студентів шостих курсів медичних факультетів, у тому числі - 150 англомовних. Воно здійснювалося шляхом створення умов для теоретичної підготовки, самостійного виконання діагностичних і лікувальних маніпуляцій на тренажерах та роботах всіх рівнів реалістичності під керівництвом лікарського і педагогічного колективів, основане на принципах проблемно-орієнтованого підходу [2, 3]. Велике значення приділялося набуттю досвіду ефективної командної роботи. Цикл навчання мав термін шість днів, всього 36 год, 3 них 2 год - лекція, 34 - практичні заняття. 72 год виділено на самостійну роботу студентів. Наприкінці циклу проводиться диференційований залік. Особлива увага приділяється діагностиці та лікуванню невідкладних станів, наприклад - симуляційний тренінг тільки з основ серцево-легеневої реанімації триває 4 год. Симуляційний тренінг за сценарієм “Фізіологічні пологи” триває 6 год. Ми вивчили швидкість виконання практичних навичок на симуляторах та роботах у всіх студентів на початку занять та після проведення симуляційного навчання. Відмічено що швидкість вірогідно $(\mathrm{p}<0,005)$ зросла в 1,9 раза, а якість виконання командної роботи при серцево-легеневій реанімації поліпшилась в 2,1 раза ( $<0,005)$. Тобто проведені цикли навчання для студентів шостих курсів медичних факультетів в Центрі дозволили майже в два рази поліпшити швидкість і якість виконання практичних навичок та командної роботи при невідкладних станах.

Висновки. 1. Підготовка студентів шостих курсів медичних факультетів 3 симуляційної медицини на базі Одеського національного медичного університету проводиться спеціалістами кафедри симуляційної медицини та Навчально-інноваційного центру практичної підготовки лікаря за загальнодержавними вимогами та сучасними світовими стандартами.

2. Перший досвід, отримані результати довели значну ефективність цих організаційних нововведень, продиктованих потребами сьогодення в медичній освіті України.

3. У результаті проведення симуляційних тренінгів серед студентів шостих курсів в Одеському 
навчально-інноваційному центрі підготовки лікаря відзначено вірогідне поліпшення майже в два рази у них показників швидкості проведення і оцінок результатів основних маніпуляцій при діагностиці та лікуванні основних невідкладних патологічних станів у медицині.

4. Проведене навчання дозволило вірогідно, майже в два рази поліпшити швидкість та якість командної роботи при невідкладних станах.

5. Симуляційний тренінг є ефективним інноваційним методом сучасного медичного навчання і рекомендується до обов'язкового використання у медичній освіті. Безцінною перевагою є відсутність

\section{Список літератури}

1. James John T. A New, Evidence-based Estimate of Patient Harms Associated with Hospital Care / John T. James // Journal of Patient Safety. - 2013. - № 9, Issue 3. P. $122-128$.

2. Артеменко В. В. Проблемно-ориентированный подход в системе симуляционного обучения медицинских работников / В. В. Артеменко, В. М. Носенко,

\section{References}

1. James, J.T. (2013). A new, evidence-based estimate of patient harms associated with hospital care. Journal of patient safety, 9(3), 122-128.

2. Artemenko, V.V., Nosenko, V.M., \& Berlinskaya, L.I. (2015). Problemno-oriyentirovannyy podkhod v sisteme simulyatsionnogo obucheniya meditsinskikh rabotnikov [Problem-oriented approach in the system of simulation training of medical personnel]. Humanitarnyi visnyk DVNZ "Pereiaslav-Khmelnytskyi derzhavnyi pedahohichnyi будь-якої небезпеки для пацієнта в ході підготовки студента.

6. Симуляційне навчання в Одеському національному медичному університеті відрізняється комплексним, системним підходом, новітніми науковими, педагогічними та навчально-методичними розробками, сучаснішою технічною базою, має широку співпрацю з міжнародними установами.

7. Навчально-інноваційний центр підготовки лікаря та кафедра симуляційної медицини ОНМедУ $є$ першими й провідними в Україні стосовно симуляційного навчання на перед- та післядипломному рівнях медичної освіти в Україні.

Л. И. Берлинская // Гуманітарний вісник ДВНЗ “Переяслав-Хмельницький державний педагогічний університет ім. Г. Сковороди”. - 2015. - Т. 5 (65), дод. 1, вип. 36. - С. 16-23.

3. Симуляционное обучение при лечении неотложных состояний в медицине / В. В. Артеменко, В. М. Носенко, Р. С. Вастьянов [и др.] // Досягнення біології та медицини. - 2015. - № 2. - С. 58-64.

universytet im. H. Skovorody - Humanitarian Bulletin of Pereiaslav-Khmelnytskyi State Pedagogical University by H. Skovoroda, 5(65), 36, 16-23 [in Russian].

3. Artemenko, V.V., Nosenko, V.M., \& Vast’yanov, R.S. (2015). Simulyatsionnoye obucheniye pri lechenii neotlozhnykh sostoyaniy $\mathrm{v}$ meditsine [Simulation learning during medical emergencies treating]. Dosiahnennia biolohii ta medytsyny - Achievements of Biology and Medicine, 2, 58-64 [in Russian]. 